\title{
Sustaining the Fertility of Artificially Inseminated Dairy Cattle: The Role of the Artificial Insemination Industry*
}

\author{
J. M. DeJarnette, C. E. Marshall, R. W. Lenz, D. R. Monke, \\ W. H. Ayars, and C. G. Sattler \\ Select Sires, Inc, \\ Plain City, OH 43064
}

\begin{abstract}
Although changes in environment and management are primarily implicated for the decline in reproductive efficiency of Holstein cows during the past $25 \mathrm{yr}$, fertility of the male must not be overlooked. Recent measures of scrotal circumference, semen quantity/ quality are comparable to values reported for Holstein sires in 1969. Technological advances in semen processing are reflected in fertilization rates using cryopreserved semen in the late 1990s comparable to those reported for non-frozen semen in the 1950s. The fertility potential of an artificial insemination (AI) dose is a function of the quantity, quality, and health status of the semen contained therein. Management of sire health and associated disease testing protocols are paramount. Semen quality evaluations, adjustments to cell numbers per dose, and culling of ejaculates and/ or bulls, minimize variation in fertility among ejaculates and/or sires released for sale. Identification of additional semen quality attributes associated with fertility may provide more accurate methods to predict, manage, and select for AI sire fertility. Because the values of most known semen quality traits are highly correlated, any new technology must be considered with respect to the additive benefit imparted compared to existing methodologies (improved fertility prediction or economic utility of implementation). Cryopreservation techniques that extend the duration of post-thaw sperm survival and/or reduce rates of capacitation may reduce sensitivity to insemination timing and are promising opportunities to improve fertility from the male perspective. Unfortunately, the association between semen quality and fertility is usually limited by the accuracy of the fertility estimate. Fixed-
\end{abstract}

Received June 27, 2003.

Accepted August 6, 2003.

Corresponding author: J. M. DeJarnette; e-mail: jmdejarnette@ selectsires.com.

*Presented at a symposium titled "The Role of the AI Sire in Maintaining Reproductive Rates of Holstein Cows" at the ADSAASAS Joint Annual Meeting, June 2003, Phoenix, AZ. time $\mathrm{AI} \geq 24 \mathrm{~h}$ prior to synchronized ovulation may provide a more sensitive model to evaluate fertility from the male or AI perspective. The role of the AI industry representative has and will continue to evolve from that of salesperson and genetic advisor to that of a reproductive and herd-management consultant. The magnitude of the decline in reproductive efficiency attributable to genetics is of considerable debate. Through semen purchasing decisions, dairy producers largely dictate the relative importance of various genetic traits to the industry and thereby the emphasis that should be placed on these traits in AI sire-sampling programs.

(Key words: artificial insemination, fertility, dairy cow, semen)

Abbreviation key: CSS = Certified Semen Services, ERCR = estimated relative conception rate, NAAB = National Association of Animal Breeders.

\section{INTRODUCTION}

The US dairy cattle population peaked in 1944 at an estimated 25.6 million animals with a total annual milk production of approximately 53.1 billion $\mathrm{kg}$ (USDA, 1961). In 1997, dairy cattle numbers had declined to 9.2 million animals and total annual production was estimated at 70.8 billion $\mathrm{kg}$ (USDA, 1997) indicating a 369\% increase in production efficiency for the average dairy cow in a little more than $50 \mathrm{yr}$. Improved efficiency of production increases profit potential for the dairy producer while facilitating industry capacity to meet rising consumer demands for a safe, wholesome, and inexpensive food supply.

Artificial insemination (AI) technology was introduced and commercialized in the United States during the late 1930s to early 1940s and has grown to a domestic market of 15.5 million units in 2002. Although a significant portion of the enhanced efficiency of milk production in the average dairy herd is the result of increased genetic potential thorough wide-spread adaptation of AI, significant advances in nutrition and management have facilitated phenotypic expression 
of genetic potential and thereby have also had major impacts on dairy production efficiency. Additional efficiencies have been realized through increases in herd size, spreading costs over more production units. The increase in average herd size has been accompanied by an evolution in management philosophies for both labor and cows that equates to more management by group and less individual cow attention.

An apparent side effect of this evolution in dairy production and management has been a negative impact on dairy herd reproductive efficiency (Washburn et al., 2002). Lucy (2001) surmised the symptoms to suggest the effects are likely the composite result of numerous interacting factors. This paper reviews the role of the AI industry in sustaining reproductive efficiency of artificially inseminated dairy cattle.

\section{THE ROLE OF THE AI INDUSTRY}

\section{Provide a Highly Fertile Product}

Inherent fertility of the Holstein sire. Although most evidence suggests the decline in dairy herd reproductive efficiency is primarily related changes in management of the female, it is logical to question the portion of this decline that can be attributed to the male. This question is particularly relevant to the genetic components of fertility that may also be expressed in measures of male reproductive capacity. Though the relationship has recently been challenged (Martínez-Velázquez et al., 2003), scrotal circumference is a measure of reproductive capacity in the male that has been associated with reproductive capacity in the female (Brinks, 1994). Scrotal circumference measurements of Holstein AI sires recorded 30 to 35 yr ago (Hahn et al., 1969b; Coulter and Foote, 1977) are basically identical in the current Holstein AI population (Select Sires, unpublished; Figure 1). Holsteins bulls maintained on intense collection schedules in 2001 and 2002 (Select Sires, unpublished) produced similar quantities of sperm as that reported by Amann and coworkers in 1974 (Table 1). A comparison of present (Select Sires, unpublished) and historic (Hahn et al., 1969a; Saacke and White, 1972; Amann et al., 1974) evaluations of neat semen in Holstein AI sires indicates similar intrinsic semen quality among the populations (motility $\geq 70 \%$; normal morphology $=75$ to $80 \%$, Figure 2). Pace (2003) reported that inbreeding (range 1 to $>19 \%$ ) among 1968 AI young sires (1994 to 2002) had no effect on measures of semen quality $\left(\mathrm{R}^{2}\right.$ range 0.0002 to 0.0062 ).

Health status of donor sire. From the onset, reduced incidence of disease transmission was readily recognized as a major advantage of AI and likely had a greater impact of the adaptation of this biotechnology than did the genetic implications. However, AI is also a very efficient means of disease transmission if appropriate precautions are not exercised in selection of the donor sire. Therefore, sire and semen health status is of paramount importance. The primary purpose of Certified Semen Services (CSS), a division of the National Association of Animal Breeders (NAAB), is to establish health testing protocols and guidelines to ensure that semen processed by participating members is accurately identified and disease free. In general, CSS requires each sire to be tested twice annually for each of 6 different diseases. However, the routine health-testing protocols of most major AI organizations greatly exceed these minimum CSS standards. In 2002, Select Sires performed in excess of 55,000 health tests on approximately 1750 sires while screening for 12 different diseases. Semen collected by nonCSS participating laboratories does not necessarily imply there are problems with the health status of the semen. Many of these facilities also follow CSS protocols and are equally disease free, however, in the absence of the CSS participation, there are no guarantees as to the semen health status. Due to increased knowledge and understanding of relevant diseases and thereby, the continual updating of CSS testing and management protocols, the health status of commercially available bovine semen is likely safer today than at any point in history.

Technological status of semen cryopreservation. Pace (2003) recently reviewed the technological advances that have been adopted by the AI industry since inception in the late 1930s. Early advances in extender formulation facilitated sperm storage in a liquid state for several days. Antibiotic addition was one of the first major advances to significantly impact the fertility potential of AI. The serendipitous discovery that glycerol facilitates cyropreservation allowed the fledging AI industry to flourish in earnest. Conversion from glass ampules and ice water thaws to French straws thawed in warm-water, dramatically increased the percentage of sperm surviving the cryopreservation process (Figure 2). Improved understanding of the components of semen quality that influence fertility and the implementation of more discriminating semen evaluation procedures, ensure with high probability that subfertile ejaculates are identified and culled prior to reaching the marketable inventory. Pace (2003) concluded: "From a technological standpoint, the dairy industry is receiving the highest quality semen ever produced." This contention is supported by the observation that in vivo fertilization rates following AI with frozen semen in recent studies (81\%, 754/ 927: Saacke et al., 1998; 83\%, 123/149: Satori et al., 2002; 79\%, 202/257: DeJarnette, unpublished) are sim- 


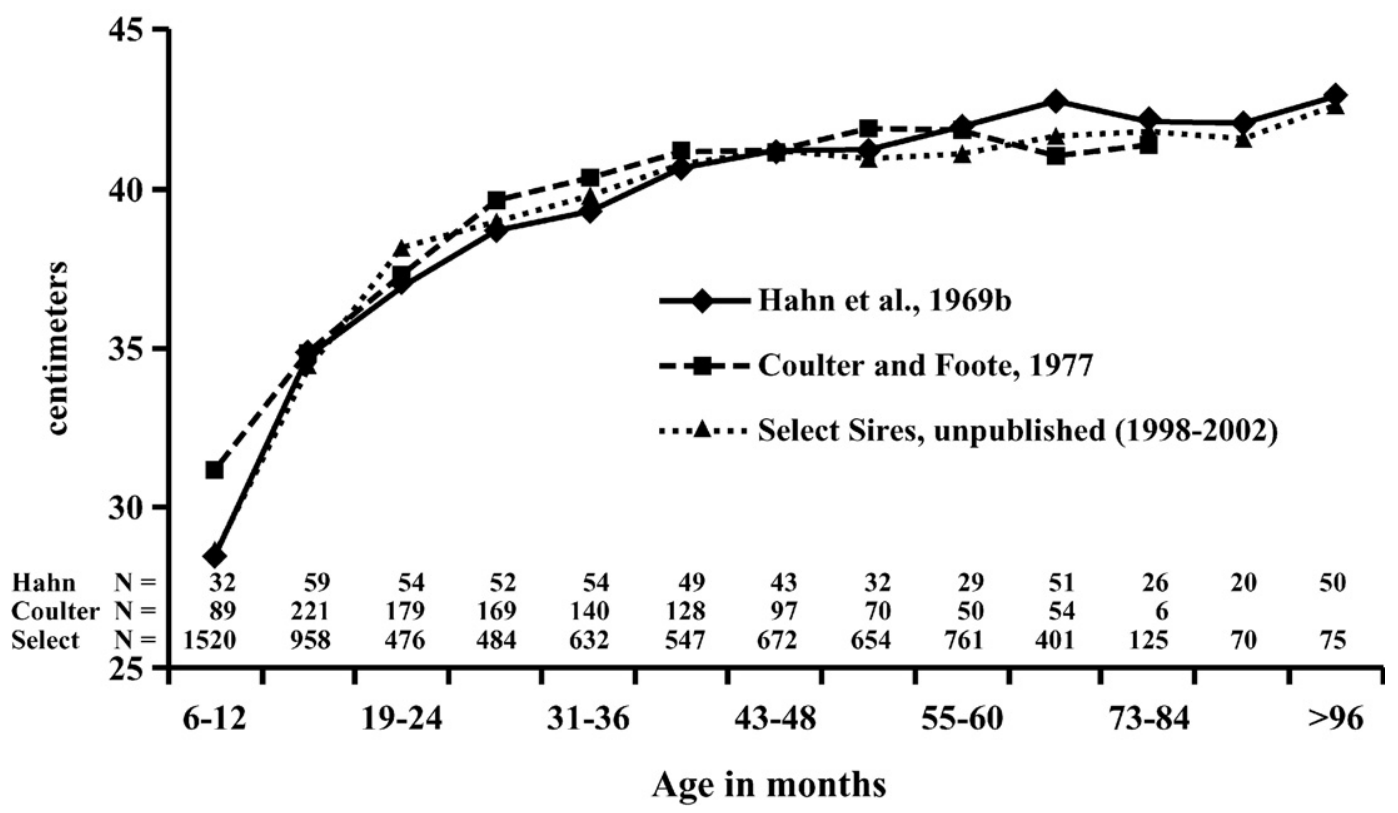

Figure 1. Comparison of scrotal circumference measures in Holstein AI sires reported in 1969, 1977 and at present. Select Sires unpublished data are reported as least square means of scrotal circumference measurements $(\mathrm{n}=11,333)$ taken on Holstein AI sires $(\mathrm{n}=$ $2867)$ between 1998 and 2002. The model included the significant effects $(P<0.001)$ of age group, technician within age group, and season of year measurement was taken.

ilar to those reported using nonfrozen semen in the 1950s (86\%, 55/64: Kidder, et al., 1954; 85\%, 41/48: Bearden et al., 1956).

Principles of semen quality control. Semen quality control programs at major AI organizations are based on principles of compensible vs. uncompensible semen quality attributes (Saacke, 1998) and their relationship to threshold sperm numbers per dose (Salisbury and VanDemark, 1961; Figure 3). Compensible semen quality traits are those for which the female population will respond to increasing numbers of sperm per AI dose with increased fertility and are associated with measures of sperm viability (i.e., mo- tility, acrosomal integrity, etc.). Uncompensible semen quality traits are those for which the female population will not display increased fertility in response to increased numbers of sperm per dose. Uncompensible traits appear to be associated with sperm morphology, DNA integrity, and the ability to sustain normal embryonic development. The "Threshold" is the value beyond which further increases in sperm numbers fail to increase fertility and may be achieved by satisfying the semen demand of the female population (Bulls A, $\mathrm{B}$, and $\mathrm{C}$ ) or when uncompensible semen quality traits become the limiting factor (Bull D). The rate at which individual bulls and/or ejaculates approach the thresh-

Table 1. Comparisons of semen production characteristics of mature Holstein AI sires on intense semen collection schedules.

\begin{tabular}{llcllll}
\hline $\begin{array}{l}\text { Age in } \\
\text { years }\end{array}$ & Reference $^{1}$ & $\begin{array}{l}\text { No. of } \\
\text { bulls }\end{array}$ & $\begin{array}{l}\text { No. of } \\
\text { months }^{2}\end{array}$ & $\begin{array}{l}\text { Volume } \\
(\mathrm{ml})\end{array}$ & $\begin{array}{l}\text { Concentration } \\
\left(\times 10^{9} / \mathrm{mL}\right)\end{array}$ & $\begin{array}{l}\text { Total sperm } \\
\left(\times 10^{9}\right)\end{array}$ \\
\hline 3.5 to 5.5 & Amann & 8 & NA & $4.6 \pm 0.40$ & $1.2 \pm 0.10$ & $5.6 \pm 0.79$ \\
& Select & 12 & $1.3 \pm 1.3$ & $6.4 \pm 0.09$ & $1.0 \pm 0.02$ & $6.4 \pm 0.16$ \\
5.5 to 7.5 & Amann & 22 & NA & $6.2 \pm 0.30$ & $1.1 \pm 0.08$ & $6.2 \pm 0.28$ \\
& Select & 18 & $5.6 \pm 1.1$ & $6.5 \pm 0.05$ & $1.0 \pm 0.01$ & $6.1 \pm 0.07$ \\
$>7.5$ & Amann & 4 & NA & $5.0 \pm 0.50$ & $1.2 \pm 0.06$ & $5.8 \pm 0.42$ \\
& Select & 4 & $1.3 \pm 2.2$ & $5.5 \pm 0.21$ & $1.1 \pm 0.05$ & $5.7 \pm 0.27$ \\
\hline
\end{tabular}

${ }^{1}$ Amann et al., 1974. Mean \pm SEM for 7 to $22(16 \pm 1)$ consecutive daily ejaculations following depletion of epididymal sperm reserves by five daily ejaculations. Select $=$ Select Sires unpublished data from 2001 and 2002. Mean \pm SEM for bulls receiving $\geq 20$ ejaculates per month $(24 \pm 0.20)$.

${ }^{2}$ Mean \pm SEM of the number of months each respective bull was maintained on the intense collection schedule. 


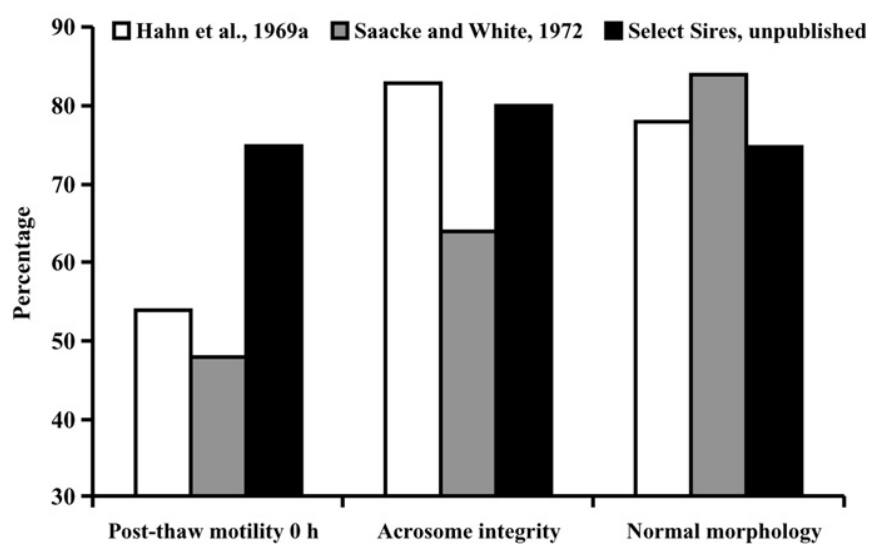

Figure 2. Comparison of semen quality characteristics of commercial AI sires in the late 1960s and at present. All comparisons are confounded by evaluater and by available technology. Hahn et al., (1969a) based on $\sim 8$ collections (16 ejaculates) taken on $\sim 60$ bulls and frozen in glass ampules. Saacke and White, 1972 based on 32 ejaculates taken on 16 bulls and frozen in glass ampules. Motility and acrosomal integrity in Select Sires unpublished data are based on 23,721 collections ( $>40,000$ ejaculates) and 7145 morphology evaluations taken of 645 sires between 01/01/2001 and 03/01/2003 and includes evaluations of samples discarded by quality control. Acrosomal integrity was measure prior to freezing (Hahn et al., 1969a) or after incubation (Saacke and White, 2 h; Select Sires, unpublished, $3 \mathrm{~h}$ ) of incubation at $37^{\circ} \mathrm{C}$.

old and the maximum level of fertility obtainable is a function of the severity and ratio of compensible and uncompensible sperm defects within the sample.

Semen quality control in practice. The primary objective of the AI center quality control program is to minimize variation in sire fertility by minimizing variation in the quality of semen made available to producers. Because most measures of semen quality associated with fertility are highly correlated with each other (Linford et al.,1976; Saacke et al., 1980), selection for one trait enriches the retained population for multiple semen quality attributes. Screening and discarding collections based on multiple semen quality traits, significantly reduces the probability that semen of less than acceptable fertility would be retained for inventory, while compensatory increases in cell numbers per dose allow marginal quality samples to obtain acceptable levels of fertility albeit at reduced efficiency of utilization. A recent survey of semen processing practices at $\mathrm{AI}$ organizations in different countries reported that the average cryopreserved AI dose contains approximately $20 \times 10^{6}$ total spermatozoa (Range 10 to $40 \times 10^{6}$; Viswanath, 2003), which is from 2 to 20 times greater than estimates of minimum threshold numbers required for normal fertilization rates (Filseth et al., 1992; van Giessen et al., 1992; den Daas et al., 1998). The success of these efforts are evidenced by multiregional fertility estimates that indicate $91 \%$ of all AI sires are within $\pm 3 \%$ of average fertility (Clay and McDaniel, 2001).

An artifact of the AI center quality control program is that the semen retained for inventory is only a small subpopulation of the potential combinations proposed by Salisbury and Van Demark (1961; Figure 4). Additionally, most attempts to associate semen quality and fertility fail to acknowledge that the accuracy of the

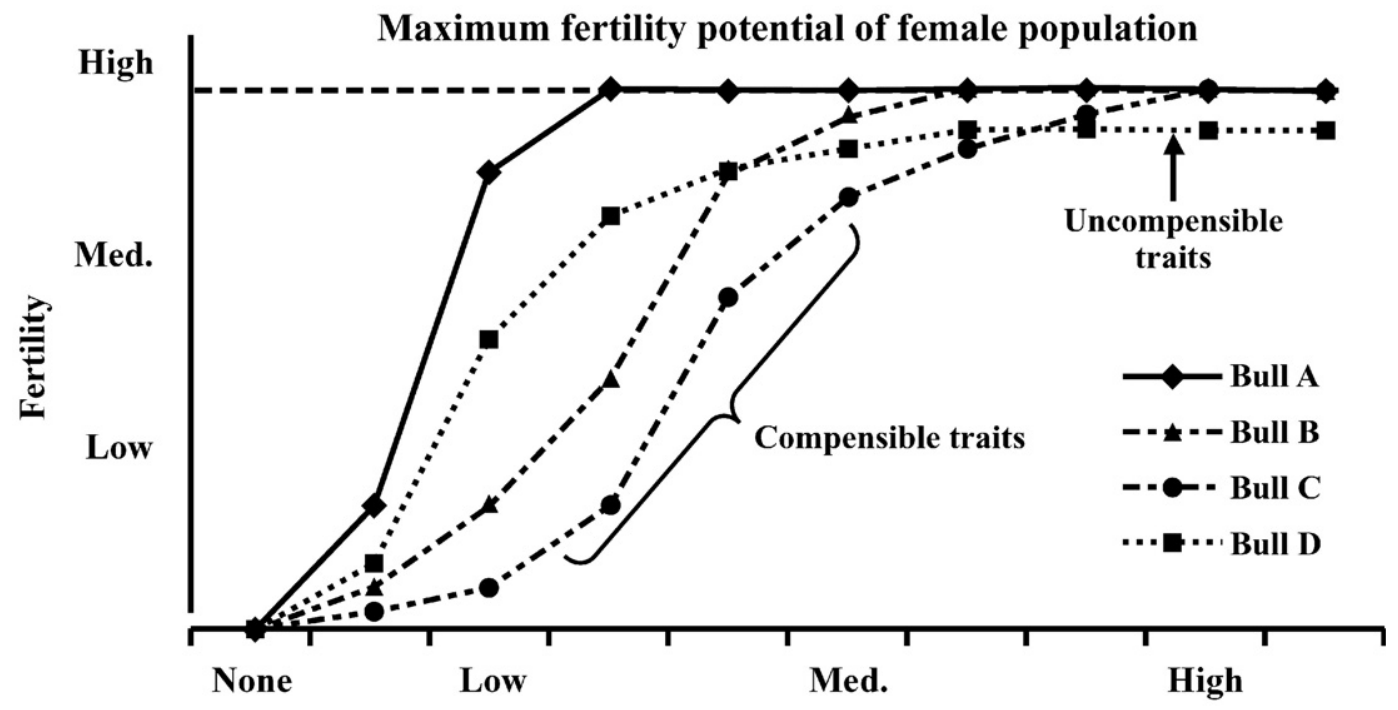

Sperm numbers per dose

Figure 3. Relationship of sperm numbers per dose and fertility for bulls of varying semen quality (Adapted from Salisbury and VanDemark, 1961). 


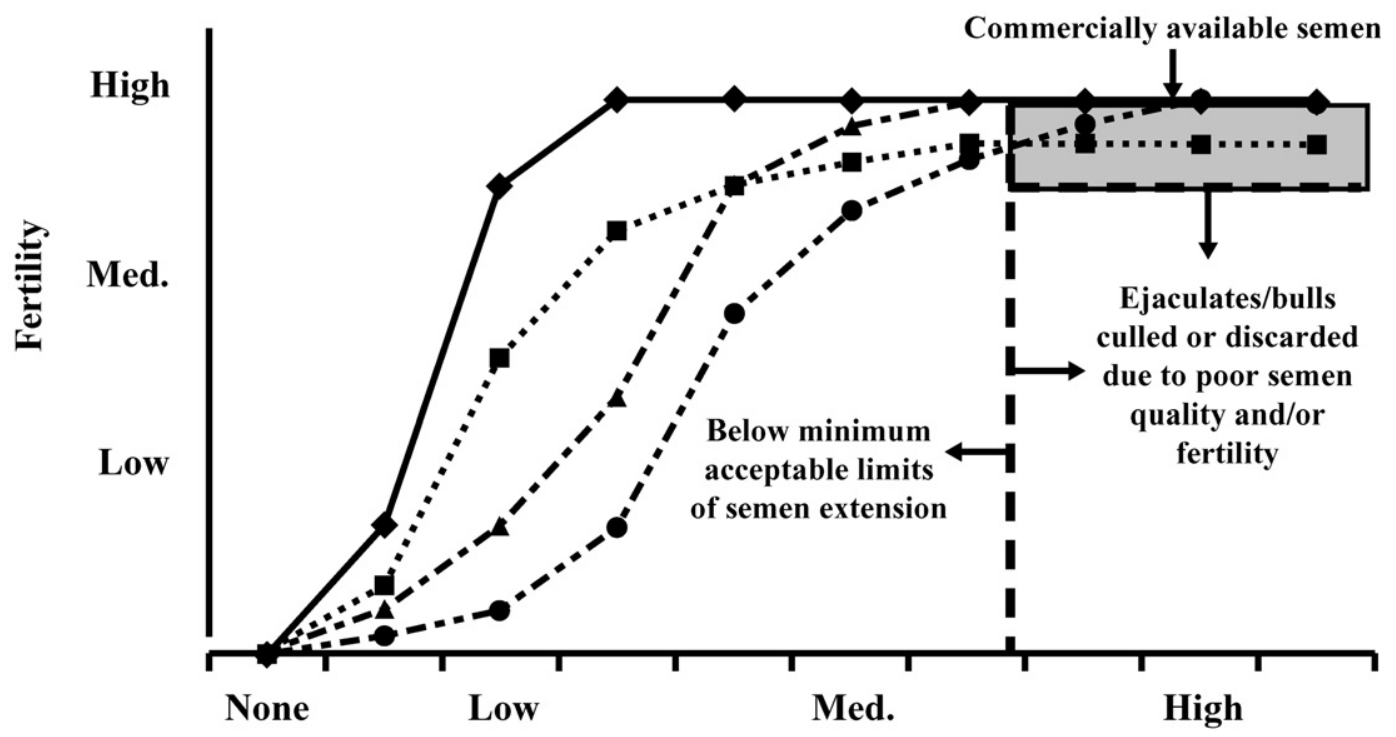

Sperm numbers per dose

Figure 4. Components of AI center quality control program that minimize variation in the quality of commercially available semen and/ or sire fertility superimposed on the principles of Salisbury and VanDeMark (1961). Typical semen extensions rates (right of vertical dashed line) in major AI centers yield sperm dosages 2 to $10 \times$ greater than the minimum numbers required to reach maximum fertility (den Daas et al., 1998; Vishwanath, 2003). Lower right quadrant represents bulls and/or ejaculates culled and discarded by quality control as evident by lack of extreme variation in multiregional estimates of AI sire fertility (Clay and McDaniel, 2001).

fertility estimate is typically the limiting factor due to the multitude of environmental and herd management factors that are only modestly accounted for in the estimate (Saacke and White, 1972; Amann and Hammerstedt, 1993; Foote, 2003). Therefore, in contrast to the research setting, it should not be surprising that most attempts to "correlate" semen quality and fertility in the "commercial" setting are exercises in futility. In reality, methods of evaluating semen quality are likely more sensitive than is our ability to accurately measure fertility within the narrow range represented by most AI sires. These observations imply that within the highly selected population of AI sires, most bulls achieve acceptable levels of fertility and that "below average" fertility should not be equated to "low fertility".

Another artifact of the AI quality control program is what often appears to be a negative correlation between cell numbers per dose and fertility. Bulls that produce marginal quality semen often achieve below average fertility despite compensatory increases in cell numbers per dose. In contrast, bulls in high demand that produce above average semen quality and fertility, usually maintain above average conception rates despite titration to below average cell numbers per dose. This phenomenon, and the control program in general, would be expected to impart positive selection pressure on fertility within the population by limiting the numbers of offspring produced by marginal fertility sires (culling bulls and ejaculates, reduced efficiency of semen utilization, below average conception) and accentuating the numbers of offspring produced by above average fertility sires (above average fertility with more efficient use of semen).

Timed-AI Sires and/or Long-Life Semen. The recent popularity of fixed-time AI protocols and evidence of differences in sire fertility within these protocols (Hiers et al., 2003) temps the question: Do some sires perform better in timed AI scenarios than do others? The obvious answer is yes, however, the more important question is: Do sire fertility rankings change in fixed-time versus estrous detection based AI protocols? To date no studies are known to specifically address this issue with a sufficient number of observations to draw meaningful conclusions. Macmillan and Watson (1975) evaluated the effects of interval from observed estrus to AI on nonreturn rates of sires with varying fertility levels. The lack of decline in nonreturn rate at early insemination among above average fertility sires (compared with average and below average fertility groups) indicates sire fertility is closely associated with sperm longevity in the female reproductive tract (Figure 5). These data imply that fixed-time AI may magnify differences in sire fertility as the interval and variance in time from AI to ovulation increases. However, the data also conversely imply that the magni- 


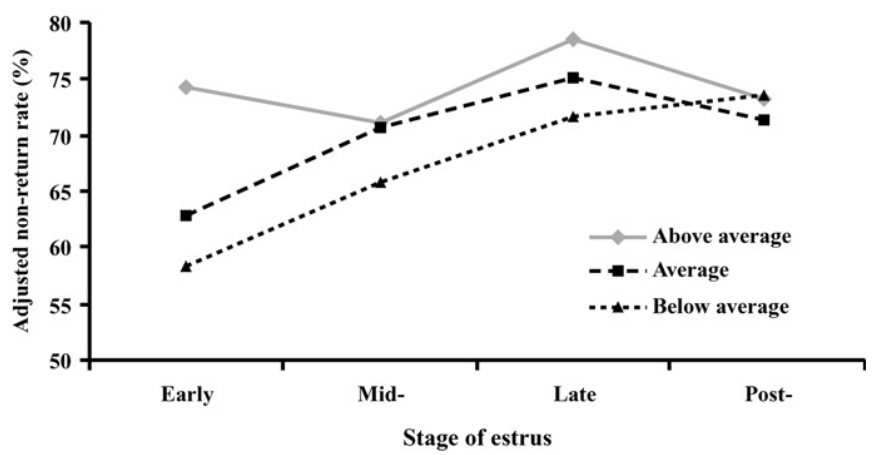

Figure 5. Effects of sire fertility group and stage of estrus at insemination on nonreturn rates. (Adapted from Macmillan and Watson, 1975).

tude of difference in sire fertility will be minimized as the synchronization protocol more precisely controls these variances. This could be particularly relevant where the accuracy of the estrous detection based AI program is deficient. Therefore, the timed AI protocol may interact with sire fertility potential to affect the magnitude of fertility difference among sires; however, there is no evidence at this time to suggest a re-ranking of sire fertility within heat detections versus timed AI scenarios should be expected.

Semen cryopreservation techniques that improve post-thaw sperm survival and thereby reduce sensitivity to insemination timing are promising areas of research to improve fertility from the male or inseminate perspective. To these ends, microencapsulation of spermatozoa for sustained time release (Vishwananth et al., 1997) or techniques designed to reduce the magnitude of cryopreservation-induced capacitation (Watson, 1995), such as prefreeze addition of cholesterol and/or antioxidants (Maxwell and Watson, 1996), show great potential. Use of "early" AI in conjunction with controlled ovulation provides a uniquely sensitive model to test the efficacy of such new treatments (Macmillan and Watson, 1975; Saacke, 1998). In theory, mixing samples of "early" and "late" capacitating sperm (Meyers et al., 1995) may achieve higher fertility by accommodating a wider ovulation window. In an unpublished Select Sires study (Figure 6), conception rates of the "mixed" samples are numerically greater than the mean of the individual bulls when used homospermically, but, not greater than those of the highest individual in the mix. These results were consistent with other studies of heterospermic inseminations (Elliott, 1974; Dzuik, 1996; Stahlberg et al., 2000) and may indicate the success of this technique is limited by accurate identification of the bulls and/or ejaculates that should be mixed.

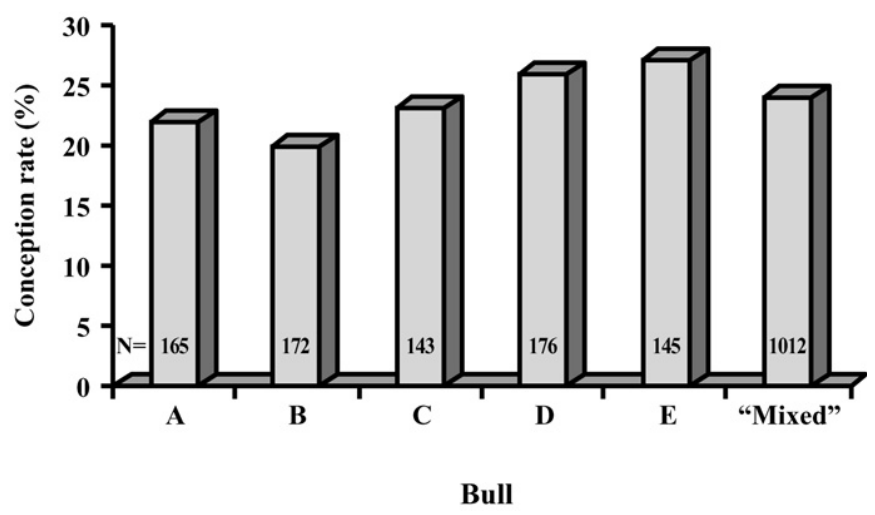

Figure 6. Effects of homo- and heterospermic ("mixed") insemination on conception rates of lactating dairy cattle in a single herd (Select Sires, Inc., unpublished). All doses contained $20 \times 10^{6}$ total spermatozoa. Using a split ejaculate technique, the heterospermic doses were prepared to contain equal total numbers of sperm from each of the 5 bulls ( $4 \times 10^{6}$ total spermatozoa from each bull).

Other opportunities. Considerable opportunities exist to further the accuracy of both predictions and estimates of sire fertility. As implied by Amann and Hammerstedt (1993), the relationship of semen quality to fertility should be investigated for degrees of "association" rather than for degrees of "correlation". Fertile sperm are those that possess sufficient levels of all known and unknown semen characteristics necessary to achieve fertilization and sustain embryo development. Semen samples that possess sufficient levels of all "known" traits must still be considered of questionable fertility because the sample could be deficient in other "unknown" or unmeasured traits. Identification of additional semen quality attributes associated with fertility will increase the odds that a positive prediction of fertility will be correct; however, the negative or low fertility prediction will always be more accurate. To these ends, the presence or absence of numerous sperm membrane and/or seminal plasma proteins and antigens associated with male fertility warrant further study (Killian et al., 1993; Bellin et al., 1996; Amann et al., 1999). Flow cytometric evaluation of semen quality has the potential to simultaneously evaluate numerous semen quality traits with a high level of precision and repeatability (Garner, 1997). However, because of the high degree of correlation among various measures of semen quality, it is essential for researchers in this field of study to portray the predictive value of any "new" semen quality attribute and/or evaluation procedure in light of prior methodology. What does the new test tell us over and above what we already knew? Is it more predictive or simply a different method to measure the same trait? If the latter, greater accuracy, sensitivity or more effi- 
cient utility of implementation must be demonstrated if wide scale application is to be expected.

\section{Provide Competent Technical Support}

The preponderance of evidence indicates changes in environment and management are primarily responsible for recent trends in dairy cattle fertility (Lucy, 2001; Senger, 2002), which appear in large part to be a function of increased rates of early embryonic mortality (Satori et al., 2002). To these ends, the role of the AI representative as a technical consultant to the dairy producer has been greatly magnified in recent years. Training and retraining on-farm employees has become a perpetual responsibility of servicing AI organizations. Keeping pace with recent advances in estrus and ovulation control has become a daunting task for even the experts in this field of study, not to mention the average AI representative or dairyman. Nutritional, cow comfort, and/or management deficiencies that had little to no influence on reproductive performance 10 to $20 \mathrm{yr}$ ago may now be a limitation to the profitability of the high producing dairy herd. In response, most AI organizations have placed increased emphasis on reproductive- and dairy herd-management consulting skills for new employees and have implemented advanced training programs to elevate these skills in both new and tenured staff.

The plethora of herd management factors influencing fertility will be avoided within the context of this manuscript; however, a detailed review of recommended semen handling procedures and recent findings pertinent to their impact on fertility is warranted.

1) Keep unused straws below the frost line in the neck-tube of the tank. The importance of keeping unused semen straws low in the storage canister cannot be over emphasized. The viability of cryopreserved semen that is re-cooled to liquid nitrogen temperatures after rising to a low as $-70^{\circ} \mathrm{C}$ is totally obliterated (DeJarnette, 1999 ) and is likely the most damaging of all semen-handling errors.

2) Thaw straws in $35^{\circ} \mathrm{C}$ water (range 33 to $37^{\circ} \mathrm{C}$ ) for a minimum of $45 \mathrm{~s}$. Despite rumors that "airthawing" prevents the potential for cold-shock during the winter months, laboratory data indicates the relative magnitude of damage induced by improper thawing procedures is significantly greater than the magnitude of damage induced by cold-shock (DeJarnette et al., 2000). However, because optimum thaw rate is a function of several interactions controlled by the processing laboratory (glycerol levels, freezing rates, package size, etc.), inseminators should always follow the specific manufacturers thawing recommendations.

3) Thaw no more straws than can be deposited in the cow within a 10 to $15 \mathrm{~min}$ period and maintain straw temperature and hygiene throughout the AI process (thaw-bath to cow). The validity of this recommendation was brought into question by 2 studies that were broadly interpreted to suggest thawing more than 2 straws at once compromises conception rates irrespective of semen handling procedures (Lee et al., 1997; Goodell, 2000). However, a recent review article (7 studies; $\mathrm{n}>19,000$ ) concluded the absolute number of straws thawed is of little concern provided recommended semen handling procedures are abided (DeJarnette et al., 2002). Failure to control semen temperature, hygiene or recommended time constraints will likely result in compromised conception rates irrespective of number of straws thawed.

4) Site of semen deposition. Most AI organizations recommend the uterine body as the proper site for semen deposition. However, nearly $90 \%$ of sperm may be lost from the female following uterine body deposition due to retrograde flow (Mitchell et al., 1985; Nelson et al., 1987). In theory, deposition of semen in the uterine horns should reduce retrograde sperm loss, facilitate sperm transport, and improve pregnancy rates to AI. However, Gallagher and Senger (1989) observed no reduction in retrograde sperm loss following cornual deposition. Studies comparing the fertility of artificially inseminated cattle after semen deposition in the uterine horns or uterine body have failed to yield consistent results (Table 2). While several studies observed improved fertility in response to horn breeding, most indicated no difference. Other studies have suggested that even following deep unilateral cornual insemination, sperm transport to the contralateral horn is quite significant (Hawk and Tanabe, 1986; Larsson, 1986; Pallares et al., 1986; Momont et., 1989; López-Gatius, 1996). Using low cell number doses (1.5 to $3.0 \times$ $10^{6}$ ) of sex sorted sperm, a significant improvement in fertility in response to bilateral horn breeding was observed in only 1 of 5 studies (Seidel et al., 1999) and conception rates after deep, unilateral deposition were similar for inseminations occurring ipsilateral or contralateral to the ovulatory follicle (Seidel et al., 1997). A synopsis of these studies clearly suggests the primary concern is to ensure that semen deposition occurs anterior to the internal cervical os. The success of deep, unilateral deposition in several studies tends to imply 
Table 2. References evaluating effects of semen deposition in the uterine horns or uterine body on measures of fertility in artificially inseminated cattle.

\begin{tabular}{|c|c|c|c|c|}
\hline Reference & $\begin{array}{l}\text { Method } \\
\text { of horn } \\
\text { breeding }\end{array}$ & Body & Horns & Probability \\
\hline & & \multicolumn{2}{|c|}{ — $\%(\mathrm{n}) \longrightarrow$} & \\
\hline Elliott, 1944 & $\mathrm{BL}$ & $65(150)$ & $62(104)$ & NS \\
\hline Brandt $1946^{2}$ & BL & $63(193)$ & $58(193)$ & NS \\
\hline Knight et al., 1951 & $\mathrm{BL}$ & $65(500)$ & $63(511)$ & NS \\
\hline Salisbury and VanDemark, 1951 & $\mathrm{BL}$ & $65(2122)$ & $65(2151)$ & NS \\
\hline Olds et al., 1953 & $\mathrm{BL}$ & $66(\sim 2400)$ & $68(\sim 2400)$ & NS \\
\hline Macpherson, 1968 & $\mathrm{UL}$ & $74(\sim 459)$ & $68(\sim 459)$ & NS \\
\hline Zavos et al., 1985 & IL & $36(\sim 55)$ & $57(\sim 55)$ & $P<0.05$ \\
\hline Fernandez-VanCleve et al., 1986 & $\mathrm{UL}^{3}$ & $34(44)$ & $42(94)$ & $\mathrm{NS}$ \\
\hline López-Gatius and Camón-Urgel, 1988 & IL & $60(174)$ & $71(160)$ & $P<0.05$ \\
\hline Senger et al., 1988 & $\mathrm{BL}$ & $45(2641)$ & $65(1537)$ & $P<0.001$ \\
\hline Williams et al., 1988 & $\mathrm{BL}$ & 48 (975) & $49(874)$ & $\mathrm{NS}$ \\
\hline Momont et al., 1989 & $\mathrm{UL}^{3}$ & $68(25)$ & $72(47)$ & NS \\
\hline McKenna et al., 1990 & $\mathrm{BL}$ & $70(2428)$ & $71(2195)$ & NS \\
\hline Graves et al., 1991 & $\mathrm{BL}$ & $63(286)$ & $54(216)$ & $P<0.10$ \\
\hline Lang-Ree, 1992 & $\mathrm{UL}$ & $62(3883)$ & $64(4161)$ & NS \\
\hline Grieger et al., 1998 & $\mathrm{BL}$ & $46(234)$ & $41(226)$ & NS \\
\hline Seidel et al., $1999^{4}$ & $\mathrm{BL}$ & 49 (239) & $57(230)$ & $P<0.05$ \\
\hline \multirow{2}{*}{\multicolumn{5}{|c|}{$\begin{array}{l}{ }^{1} \text { Methods of horn breeding are defined as follows: } \mathrm{BL}=\text { bilateral deposition; } \mathrm{IL}=\text { ipsilateral to expected } \\
\text { side of impending ovulation; UL = unilateral deposition irrespective of impending ovulation. }\end{array}$}} \\
\hline & & & & \\
\hline \multicolumn{5}{|c|}{$\begin{array}{l}{ }^{2} \text { As cited by Salisbury and VanDemark, } 1951 . \\
{ }^{3} \text { Side of ovulation was retrospectively evaluated and differences were not significant for ipsilatereral vs. } \\
\text { contralateral semen deposition. }\end{array}$} \\
\hline \multicolumn{5}{|c|}{$\begin{array}{l}{ }^{4} \text { Data are presented as summary of } 5 \text { separate studies evaluating low cell number dosages of sexed sorted } \\
\text { sperm. Results were only significantly different within a single study. }\end{array}$} \\
\hline
\end{tabular}

the extra time and effort necessary for bilateral deposition may not be justified; however, a direct comparison of these techniques does not appear to exist in the literature. If necessary, bilateral horn-breeding procedures would be a relatively simple method to implement by experienced AI technicians; however, whether the novice could be trained in these procedures without creating more problems than have been solved is debatable. In either case, the accuracy and efficiency of the training processes can be facilitated by incorporation of ultrasonic methods for determination of site of deposition as developed and described by Beal et al. (1989).

5) Inseminate only cows that are actually in estrus (or induced to ovulate) at timings that are consistent with the "AM/PM Rule". The founding studies upon which recommendations for insemination timing in cattle were developed (Trimberger and Davis, 1943; Trimberger, 1948) indicate cows should be inseminated $\sim 12 \mathrm{~h}$ after the initial standing mount. These data eventually became extrapolated into $\sim 12 \mathrm{~h}$ after first "observed" standing mount and adapted into what has become widely known as "The AM/PM Rule". In a retrospective study of estrus and insemination data obtained from 17 herds using an auto- mated estrous detection system, Dransfield et al. (1998) determined optimum conception rates to occur at 4 to $12 \mathrm{~h}$ after the first standing mount, which appeared to be consistent with Trimberger and Davis (1943). However, Dransfield also noted that the average cow had been in estrus for $6 \mathrm{~h}$ when first visually observed by herd employees. The notable decrease in conception rates at insemination intervals exceeding $16 \mathrm{~h}$ from first mount to AI brought to question the legitimacy of the AM/ PM rule. These concerns are further supported by data indicating high rates of early embryonic mortality when inseminations occur at 24 compared with 0 or $12 \mathrm{~h}$ after the first mount (Saacke, 1998). These studies imply the AM/PM rule is most effective in herds with very intense and accurate estrous detection programs. However, reality dictates that the average dairy herd estrous detection program is not sufficiently intense to identify time of first mount with the necessary precision to allow the AM/PM rule to reach its full potential and thereby explains why others have demonstrated comparable conception rates in once vs. twice daily insemination programs (Nebel et al., 1994).

Discarding rules of thumb that have served the industry well for many years is very difficult. However, 
a summary of available data taken in light of the realities dairy herd management and estrous detection programs would suggest guidelines for timing of AI should be modified to recommend: 1) Cows detected in estrus should be inseminated at the next convenient opportunity and no later than 10 to $12 \mathrm{~h}$ after detected estrus, and 2) When appropriate insemination timing is in question, early insemination is less likely to compromise conception.

The prerequisite that only cows in estrus are presented for insemination cannot be overemphasized. The percentage of nonestrus cows presented for AI has been estimated as high as $46 \%$ and was determined to be a significant cause for low conception (Nebel et al., 1987; Sturman et al., 2000). This issue is particularly relevant with respect to previously inseminated cows wherein studies have indicated nonestrus inseminations are 60 to $90 \%$ efficacious for inducing abortion in previously inseminated and pregnant cows (Sturman et al., 1980; Weaver et al., 1989). As increased numbers of large herds opt for breeding programs based almost exclusively on tail-chalk and/or other secondary signs of estrus, the magnitude of the problem will likely be exacerbated. Hypersensitivity to low fertility has created a sense of urgency in many herds to inseminate every cow at the slightest indication of any sign of estrus. This approach is likely counterproductive to overall reproductive efficiency. A more conservative approach to diagnosis of estrus in previously inseminated cows will reduce input cost, improve both conception and pregnancy rates, and thereby dramatically impact the profitability of the operation.

\section{Provide Superior Genetics}

A major responsibility of the AI industry is to supply genetics that are in demand by the dairy industry. It is not the responsibility of the AI industry to dictate to the producer what type of cattle they should be breeding nor to narrowly define what types of genetic packages will be offered for sale to the industry. Although AI representatives often provide advice and consultation where appropriate, the ultimate genetic decision is made by the dairy producer whose views, opinions and priorities are expressed in their semen purchases. Based on present sales trends and any anticipated changes in the types of cattle dairymen want in their herds 6 to $10 \mathrm{yr}$ from now, industry geneticist make the corresponding efforts to identify and sample the appropriate young sire pedigrees expected to meet those demands. The total cost to sample an AI sire is estimated at $\sim \$ 30,000$ and typically only $\sim 10 \%$ are retained for marketing after receiving genetic evaluations. Thus, each proven sire retained for marketing represents an investment in excess of $\sim \$ 300,000$. Proven sires for which only marginal market demand presently exists must be considered extremely highrisk endeavors in terms of siring sons that would possess substantial market demand.

Genetic selection in the dairy cow has primarily focused on production and type traits with little to no emphasis on reproduction other than calving ease. Reproduction has received little attention in the selection process for several very logical reasons. Low estimates of heritability for reproduction indicate a very slow rate of genetic progress if selecting for this trait (Nadarajah et al., 1988; Stälhammar et al., 1994). Secondly, methods of measuring fertility in male and especially female bovine have been considered deficient in the fundamental accuracy that is a prerequisite to reliable estimates of genetic merit. However, hypersensitivity of the industry to the apparent decline in dairy cattle reproductive efficiency appears to be steering us towards genetic selection for fertility despite these limitations. The first genetic evaluations for daughter fertility in the US were released in February 2003 (VanRaden and Tooker, 2003). While these evaluations indicate possibilities to select for both production and reproduction, the relationship between these traits appears to be antagonistic (VanRaden et al., 2002). However, the present model assumes a $60-d$ voluntary waiting period for all cows and does not adjust for the common management practice of extended voluntary waiting periods for high producing cows (Arbel et al., 2001) which will invariably confound genetic estimates of fertility and/or relationships to milk production. Additionally, the genetic component of reduced fertility in the Holstein cow is puzzling when consideration is given to the intense selection pressure for fertility practiced in dairy sires for the past $60 \mathrm{yr}$ and the anecdotal observation that reproductive efficiency of virgin heifers does not appear to have declined.

As the industry embarks on any "new" genetic path, it's important to remember that a significant impact on the population will not likely occur for $\sim 10 \mathrm{yr}$. Contract-matings made today result in bull calves that are born a year from now and collected and sampled a year thereafter. Daughters of these sires will be born in 3 , bred in 4 , calve in 5 and complete their first lactation $6 \mathrm{yr}$ from now. A subpopulation of these sires (10 to 15\%) will be brought back into production for widespread semen distribution. The bulk of female offspring produced from today's genetic sampling decisions will not enter the milking herd for 9 to $10 \mathrm{yr}$. Cows entering the milking herd today are a result of genetic selection believed to be important $10 \mathrm{yr}$ ago. Therefore, whatever the portion of reduced reproduc- 
tive efficiency in the Holstein dairy cow is due to genetics, it did not occur nor will we make it disappear, overnight. The low heritability of fertility magnifies the importance of accuracy in estimates of genetic merit for fertility if this decline in reproductive efficiency is to be thwarted through genetic selection. The $\mathrm{AI}$ and dairy industries must proceed cautiously and deliberately in their efforts to genetically select for improved fertility, while mindful that modifications to environment and management will often have a greater and more immediate impact.

\section{SUMMARY AND CONCLUSION}

A multitude of environmental and management factors have been implicated in the decline in dairy herd reproductive efficiency, however, the fertility of the Holstein male should not be overlooked. The AI industry must continue to maintain intense quality control programs to ensure cryopreserved semen released for sale is disease-free and highly fertile. Technical support and training is a growing responsibility of the AI industry representative as this role evolves to a reproductive and herd-management consultant. The AI industry must increase research efforts to improve, predict, and/or measure fertility in both males and females. The AI industry must continue to supply the genetic resources for the dairy industry's specific breeding objectives; however, the emphasis placed on production, type, and/or reproduction in AI sire sampling programs will be largely directed by dairy producers through exercise of their semen purchasing options. The greatest challenge the AI industry will face is how to provide technical support and sponsor research while price competition drives the industry ever closer to a commodity market.

\section{REFERENCES}

Amann, R. P., and R. H. Hammerstedt. 1993. In vitro evaluation of semen quality: An opinion. J. Androl. 14:397-406.

Amann, R. P., J. F. Kavanaugh, L. C. Griel, Jr., and J. K. Voglmayr. 1974. Sperm production of Holstein bulls determined from testicular spermatid reserves, after cannulation of rete testis or vas deferens, and by daily ejaculation. J. Dairy Sci. 57:93-99.

Amann, R. P., G. E. Seidel, Jr., and Z. A. Brink. 1999. Exposure of thawed frozen bull sperm to a synthetic peptide before artificial insemination increase fertility. J. Androl. 20:42-46.

Arbel, R., Y. Bigun, E. Ezra, H. Sturman, and D. Hojman. 2001. The effect of extended calving intervals in high-yielding lactating cows on milk production and profitability. J. Dairy Sci. 84:600-608

Beal, W. E., R. B. Edwards, III, and J. M. Kearnan. 1989. Use of B-mode, linear array ultrasonography for evaluating the technique of bovine artificial insemination. J. Dairy Sci. 72:21982202.

Bearden, H. J., W. M. Hansel, and R. W. Bratton. 1956. Fertilization and embryonic mortality rates of bulls with histories of either low or high fertility in artificial breeding. J. Dairy Sci. 39:312-318.
Bellin, M. E., H. E. Hawkins, J. N. Oyarzo, R. J. Vanderboom, and R. L. Ax. 1996. Monoclonal antibody detection of heparin-binding proteins on sperm corresponds to increased fertility of bulls. J. Anim. Sci. 74:173-182.

Brinks, J. S. 1994. Relationships of scrotal circumference to puberty and subsequent reproductive performance in male and female offspring. Pages 363-370 in Factors Affecting Calf Crop. M. J. Fields and R. S. Sand, CRC Press, Boca Raton, FL.

Clay, J. S., and B. T. McDaniel. 2001. Computing mating bull fertility from DHI nonreturn data. J. Dairy Sci. 84:1238-1245.

Coulter, G. H., and R. H. Foote. 1977. Relationship of body weight to testicular size and consistency in growing Holstein bulls. J. Dairy Sci. 44:1076-1079.

DeJarnette, J. M. 1999. Factors affecting the quality of frozen semen after thawing. Pages 267-276 in Proc. Soc. Theriogenol.; Semen Cryopreservation Artif. Insem. Symp., Nashville, TN.

DeJarnette, J. M., D. A. Barnes, and C. E. Marshall. 2000. Effects of pre- and post-thaw thermal insults on viability characteristics of cyropreserved bovine semen. Theriogenology 53:1225-1238.

DeJarnette, J. M., R. W. Shephard, M. T. Kaproth, N. A. Michael, J. C. Dalton, G. M. Goodell, and C. N. Lee. 2002. Effects of sequential insemination number after batch-thawing on conception rates of cryopreserved bovine semen: a review. Pages 102110 in Proc. XIX Tech. Conf. Artif. Insem. Reprod. Natl. Assoc. Anim. Breeders.

den Daas, J. H. G., G. de Jong, L. M. T. E. Lansbergen, and A. M. van Wagtendonk-de Leeuw. 1998. The relationship between the number of spermatozoa inseminated and the reproductive efficiency of individual dairy bulls. J. Dairy Sci. 81:1714-1723.

Dransfield, M. B. G., R. L. Nebel, R. E. Pearson, and L. D. Warnick. 1998. Timing of insemination for dairy cows identified in estrus by a radiotelemetric estrus detection system. J. Dairy Sci. 81:1874-1882.

Dziuk, P. J. 1996. Factors that influence the proportion of offspring sired by a male following heterospermic insemination. Anim. Reprod. Sci. 43:65-88.

Elliott, F. I. 1944. Studies on some problems related to the successful artificial insemination of dairy cattle. Ph.D. thesis, Cornell University, Ithaca, NY.

Elliott, F. I. 1974. Heterospermic trials at ABS. Pages 65-66 in Proc. V Tech. Conf. Artif. Insem. Reprod. National Assoc. Anim. Breeders.

Fernández-VanCleve, J., P. M. Zavos, G. Heersche, Jr., and D. E. Miksch. 1986. The influence of site of semen deposition on conception in artificially inseminated (AI) cows and heifers. J. Anim. Sci. 63(Suppl. 1):65. (Abstr.)

Filseth, O., K. Komisrud, and T. Graffer. 1992. Effect of dilution rate on fertility of frozen bovine semen. Proc. XII Intl. Cong. Reprod. Artif. Insem. (Hague) Vol III:1409-1411.

Foote, R. H. 2003. Fertility estimation: a review of past experience and future prospects. Anim. Reprod. Sci. 75:119-139.

Gallagher, G. R., and P. L. Senger. 1989. Concentrations of spermatozoa in the vagina of heifers after deposition of semen in the uterine horns, uterine body or cervix. J. Reprod. Fert. 86:19-25.

Garner, D. L. 1997. Ancillary test of bull semen quality. Food Anim. Prac. 13:313-330.

Goodell, G. 2000. Comparison of AI pregnancy rates in dairy cattle by order of preparation of insemination straws. J. Anim. Sci. 78(Suppl. 1):229(Abstr.).

Graves, W. M., H. H. Dowlen, G. A. Kiess, and T. L. Riley. 1991. Evaluation of uterine body or bilateral uterine horn insemination techniques. J. Dairy Sci. 74:3454-3456.

Grieger, D. G., G. C. Lamb, T. G. Rozell, K. E. Thompson, and J. S. Stevenson. 1998. Site of semen deposition and fertility in beef cows inseminated according to estrus or at a fixed time after synchronization with GnRH-PGF ${ }_{2 \alpha}$. J. Anim. Sci. 76(Suppl. 1):279. (Abstr.)

Hahn, J., R. H. Foote, and G. E. Seidel, Jr. 1969a. Quality and freezability of semen from growing and aged dairy bulls. J. Dairy Sci. 52:1843-1848.

Hahn, J., R. H. Foote, and G. E. Seidel, Jr. 1969b. Testicular growth and related sperm output in dairy bulls. J. Anim. Sci. 29:41-47. 
Hawk, H. W., and T. Y. Tanabe. 1986. Effect of unilateral cornual insemination upon fertilization rate in superovulating and single-ovulating cattle. J. Anim. Sci. 63:551-560.

Hiers, E. A., C. R. Barthle, M. K. V. Dahms, G. E. Portillo, G. A. Bridges, D. O. Rae, W. W. Thatcher, and J. V. Yelich. 2003. Synchronization of Bos indicus $\times$ Bas Taurus cows for timed artificial insemination using gonadotropin-releasing hormone plus prostaglandin $\mathrm{F}_{2 \alpha}$ in combination with melengestrol acetate. J. Anim. Sci. 81:830-835.

Kidder, H. E., W. G. Black, J. N. Wiltbank, L. C. Ulberg, and L. E. Casida. 1954. Fertilization rates and embryonic death rates in cows bred to bulls of different levels of fertility. J. Dairy Sci. 37:691-697.

Killian, G. J., D. A. Chapman, and L. A. Rogowski. 1993. Fertilityassociated proteins in Holstein bull seminal plasma. Biol. Reprod. 49:1202-1207.

Knight, C. W., T. E. Patrick, H. W. Anderson, and C. Branton. 1951. The relation of site of semen deposit to breeding efficiency of dairy cattle. J. Dairy Sci. 34:199-202.

Lang-Ree, J. R. 1992. Influence of site of insemination on bovine fertility. XII Intl. Cong. Anim. Reprod. Artif. Insem., The Hague 3:1572. (Abstr.)

Larsson, B. 1986. Transuterine transport of spermatozoa after artificial insemination of heifers. Anim. Reprod. Sci. 12:115-122.

Lee, C. N., T. Z. Huang, and A. B. Sagayaga. 1997. Conception rates in dairy cattle are affected by the number of semen straws thawed for breeding. J. Dairy Sci. 80(Suppl. 1):151. (Abstr.)

Linford, E., F. A. Glover, C. Bishop, and D. L. Stewart. 1976. The relationship between semen evaluation methods and fertility in the bull. J. Reprod. Fertil. 47:283-291.

López-Gatius, F. 1996. Side of gestation in dairy heifers affects subsequent sperm transport and pregnancy rates after deep insemination into one uterine horn. Theriogenology 45:417-425.

López-Gatius, F., and J. Camón-Urgel. 1988. Increase of pregnancy rate in dairy cattle after preovulatory follicle palpation and deep cornual insemination. Theriogenology 29:1099-1103.

Lucy, M. C. 2001. Reproductive loss in high-producing dairy cattle: Where will it end? J. Dairy Sci. 84:1277-1293.

Macmillan, K. L., and J. D. Watson. 1975. Fertility differences between groups of sires relative to the stage of oestrus at the time of insemination. Anim. Prod. 21:243-249.

Macpherson, J. W. 1968. Semen placement effects on fertility in bovines. J. Dairy Sci. 51:807.

Marshall, C. E., W. M. Graves, J. L. Meador, J. B. Swain, and J. I. Anderson. 1989. A fertility comparison of uterine body and bicornual semen deposition procedures in dairy cattle. J. Anim. Sci. 67(Suppl. 1):455. (Abstr.)

Martínez-Veláquez, G., K. E. Gregory, G. L. Bennett, and L. D. Van Vleck. 2003. Genetic relationships between scrotal circumference and female reproductive traits. J. Anim. Sci. 81:395-401.

Maxwell, W. M. C., and P. F. Watson. 1996. Recent progress in the preservation of ram semen. Anim. Reprod. Sci. 42:55-65.

McKenna, T., R. W. Lenz, S. E. Fenton, and R. L. Ax. 1990. Nonreturn rates of dairy cattle following uterine body or corneal insemination. J. Dairy Sci. 73:1779-1783.

Meyers, S. A., J. W. Overstreet, I. K. M. Liu, and E. Z. Drobnis. 1995. Capacitation in vitro of stallion spermatozoa: comparison of progesterone-induced acrosome reactions in fertile and subfertilte males. J. Androl. 16:47-54.

Mitchell, J. R., P. L. Senger, and J. L. Rosenberger. 1985. Distribution and retention of spermatozoa with acrosomal and nuclear abnormalities in the cow genital tract. J. Anim. Sci. 61:956-967.

Momont, H. W., B. E. Seguin, G. Singh, and E. Stasiuknas. 1989. Does intrauterine site of insemination in cattle really matter? Theriogenology 32:19-26.

Nadarajah, K., E. B. Burnside, and L. R. Schaeffer. 1988. Genetic parameter for fertility of dairy bulls. J. Dairy Sci. 71:2730-2734.

Nebel, R. L., W. L. Walker, M. L. McGilliard, C. H. Allen, and G. S. Heckman. 1994. Timing of insemination of dairy cows: fixed time once daily versus morning and afternoon. J. Dairy Sci. 77:3185-3191.
Nebel, R. L., W. D. Whittier, B. G. Cassell, and J. H. Britt. 1987. Comparison of on-farm and laboratory milk progesterone assays for identifying errors in detection of estrus and diagnosis of pregnancy. J Dairy Sci. 70:1471-1476.

Nelson, V. E., E. P. Aalseth, C. H. Hawman, G. D. Adams, L. J. Dawson, and R. W. McNew. 1987. Sperm discharge and distribution within the cow's reproductive tract after AI. J. Anim. Sci. 65(Suppl. 1):401. (Abstr.)

Olds, D., D. M. Seath, M. C. Carpenter, and H. L. Lucas. 1953 Interrelationships between site of deposition, dosage, and number of spermatozoa in diluted semen and fertility of dairy cows inseminated artificially. J. Dairy Sci. 36:1031-1035.

Pace, M. M. 2003. Has the fertilizing capacity of bovine spermatozoa changed? Pages 13 to 21 in Reproductive loss in dairy cows: Is the trend reversible? Proc. II Bi-Annual W. E. Petersen Symp., University of MN-St. Paul Campus, Minneapolis, MN.

Pallares, A., P. M. Zavos, and R. W. Hemken. 1986. Fertilization rates and embryonic development in superovulated cattle inseminated in different sites within the reproductive tract. Theriogenology 26:709-719.

Saacke, R. G. 1998. AI fertility: Are we getting the job done? Pages 6-13 in Proc. 17th Tech. Conf. Artif. Insem. and Reprod., Natl. Assoc. Animal Breeders, Columbia, MO.

Saacke, R. G., W. E. Vinson, M. L. O'Connor, J. E. Chandler, J. K. Mullins, R. P. Amann, C. E. Marshall, R. A. Wallace, W. N. Vincel, and H. C. Kellgren. 1980. The relationship of semen quality and fertility. Pages 71-78 in Proc. 8th Tech. Conf. Artif. Insem. Reprod., Natl. Assoc. Anim. Breeders, Columbia, MO.

Saacke, R. G., and J. M. White. 1972. Semen quality tests and their relationship to fertility. Pages 22-27 in Proc. 4th Tech. Conf. Artif. Insem. Reprod., Natl. Assoc. Anim. Breeders, Columbia, MO.

Salisbury, G. W., and N. L. VanDemark. 1951. The effect of cervical, uterine and cornual insemination on fertility of the dairy cow. J. Dairy Sci. 34:68-74.

Salisbury, G. W., and N. L. VanDemark. 1961. Significance of semen quality. Pages 359-379 in Physiology of reproduction and artificial insemination in cattle. 1st ed. W. H. Freeman and Co., San Francisco, CA.

Sartori, R., R. Sartor-Bergfelt, S. A. Mertens, J. N. Guenther, J. J. Parrish, and M. C. Wiltbank. 2002. Fertilization and early embryonic development in heifers and lactating cows in summer and lactating and dry cows in winter. J. Dairy Sci. 85:2803-2812.

Seidel, G. E., Jr., J. L. Schenk, L. A. Herickhoff, S. P. Doyle, Z. Brink, R. D. Green, and D. G. Cran. 1999. Insemination of heifers with sexed sperm. Theriogenology 52:1407-1420.

Senger, P. L. 2002. Fertility factors-which ones are really important? Proc. Am. Assoc. Bovine Pract. 35:112-123.

Senger, P. L., W. C. Becker, S. T. Davidge, J. K. Hillers, and J. J. Reeves. 1988. Influence of cornual insemination on conception rate in dairy cattle. J. Anim. Sci. 66:3010-3016.

Stahlberg, R., B. Harlizius, K. F. Weitze, and D. Waberski. 2000. Identification of embryo paternity using polymorphic DNA markers to assess fertilizing capacity of spermatozoa after heterospermic insemination in boars. Theriogenology 53:1365-1373.

Stälhammar, E. M., L. Janson, and J. Philipsson. 1994. Genetic studies of fertility in A. I. Bulls. II. Environmental and genetic effects on non-return rates of young bulls. Anim. Reprod. Sci. 34:193-207.

Sturman, H., A. Bakhar, and Z. Ben-Smuel. 1980. Rate of incidence and damage caused by insemination of cows not in estrus in large dairies in Israel. 9th Intl. Cong. Anim. Reprod. Artif. Insem., Madrid 3:236. (Abstr.)

Sturman, H., E. A. B. Oltenacu, and R. H. Foote. 2000. Importance of inseminating only cows in estrus. Theriogenology 53:1657-1667.

Trimberger, G. W. 1948. Breeding efficiency in dairy cattle from artificial insemination at various intervals before and after ovulation. Nebraska Agric. Exp. Stn. Res. Bull. 153:1-26.

Trimberger, G. W., and H. P. Davis. 1943. Conception rate in dairy cattle from artificial insemination at various stages of estrus. Nebraska Agric. Exp. Stn. Res. Bull. 129:1-14. 
USDA. 1961. Milk. Cows on farms, production per cow, and total production. Statistical reporting service, Crop reporting board, Stat. Bull. No. 289.

USDA. 1999. Milk cows and production, final estimates 1993-97. Natl. Agric. Statistics Service Publ. 952.

van Giessen, R. C., C. A. Zuidberg, W. Wilmink, W. v/d Veene, and N. den Daas. 1992. Optimum use of a bull with high genetics. Proc. XII Intl. Cong. Reprod. Artif. Insem. Vol. III:1493-1495, The Hague, The Netherlands.

VanRaden, P. M., H. D. Norman, and R. H. Miller. 2002. Correlations among measures of dairy cattle fertility and longevity. J. Dairy Sci. 85(Suppl. 1):88. (Abstr.)

VanRaden, P. M., and M. E. Tooker. 2003. Definition of traits and comparison of models for genetic evaluation of cow fertility. J. Dairy Sci. J. Dairy Sci. 86(Suppl. 2):131. (Abstr.).

Vishwanath, R. 2003. Artificial insemination: the state of the art. Theriogenology 59:571-584.

Vishwananth, R., R. L. Nebel, W. H. McMillan, C. J. Pitt, and K. L. Macmillan. 1997. Selected times of insemination with micro- encapsulated bovine spermatozoa affect pregnancy rates of synchronized heifers. Theriogenology 48:369-376.

Washburn, S. P., W. J. Silvia, C. H. Brown, B. T. McDaniel, and A. J. McAllister. 2002. Trends in reproductive performance in southeastern Holstein and Jersey DHI herds. J. Dairy Sci. 85:244-251.

Watson, P. F. 1995. Recent developments and concepts in the cryopreservation of spermatozoa and the assessment of their postthawing function. Reprod. Fertil. Dev. 7:213-233.

Weaver, L. D., C. A. Daley, and C. L. Borelli. 1989. Effect on pregnancy rate on nonestrus insemination in previously inseminated dairy cows. Theriogenology 32:603-606.

Williams, B. L., F. C. Gwazdauskas, W. D. Whittier, R. E. Pearson, and R. L. Nebel. 1988. Impact of site of inseminate deposition and environmental factors that influence reproduction of dairy cattle. J. Dairy Sci. 71:2278-2283.

Zavos, P. M., J. T. Johns, G. Heersche, Jr., and D. E. Miksch. 1985. Site of semen deposition and subsequent conception in synchronized and artificially inseminated (AI) beef heifers. J. Anim. Sci. 61(Suppl. 1):37. (Abstr.) 